\title{
III Congresso Internacional

\section{"DO COCO DE RODA AO SIRIRI": A IMPORTÂNCIA DA EDUCAÇÃO MUSICAL NO DESENVOLVIMENTO ESCOLAR DAS CRIANÇAS DA COMUNIDADE QUILOMBOLA DO BARRO BRANCO}

\author{
Apresentação: Pôster \\ Autor Principal ${ }^{1}$ Johnne Lendon Cardoso Lins; Coautor ${ }^{2}$ Iago Silva Rodrigues; Orientador ${ }^{3}$ \\ Jandson Ferreira da Silva
}

\section{Introdução}

O presente texto vem mostrar como se desenvolveu os estágios supervisionados I e II realizado pelos alunos de música na comunidade Quilombola do Barro Branco, situada na zona rural do município Belo Jardim. Nele é possível observar a importância da música no desenvolvimento das crianças quilombolas e como as metodologias de ensino utilizadas na formação docente do licenciando podem promover novas adaptações à realidade educacional, principalmente, quando são transpostas do campo teórico para o campo de estágio. Traz também, as metodologias usadas e mostra os resultados alcançados a partir do estágio e da inserção da educação musical. A escolha dessa escola para estagiar e a proposta de pesquisação foi motivada pela necessidade de dar continuidade aos conhecimentos desenvolvidos pela comunidade, durante o projeto de extensão que os estagiários participaram nos dois anos anteriores ao estágio curricular. Como a intervenção do projeto de extensão não se expandiu até a escola, a pesquisação - através do estágio - oportunizou o trabalho com a música e as tradições orais também aos atores escolares. O mais importante aqui não é discutir sobre os rumos da educação musical, mas trazer para reflexão uma experiência de ensino onde os alunos puderam entender a importância e significado da música na escola.

\footnotetext{
1 Licenciatura em Música, IFPE- Campus- Belo Jardim, e-mail: Johnnelclins.tuba@ gmail.com

2 Licenciatura em Música, IFPE- Campus - Belo Jardim, e-mail: iago.rodrigues18@ hotmail.com

3 Mestre, IFPE- Campus - Belo Jardim, E-mail: jandson.silva@belojardim.ifpe.edu.br
} 


\section{Aprendizagem em música: um olhar sobre a construção do conhecimento}

Para Piaget (1993),a aprendizagem ocorre através dos processos de assimilação e de acomodação, e, ainda, através dos esquemas. No processo de assimilação, o sujeito cognitivo busca englobar as informações vindas do meio a fim de aumentar seu conhecimento. Durante este processo, há uma seleção natural dos principais conteúdos. O desenvolvimento geral do individuo será resultado de suas potencialidades genéticas e, sobretudo, das habilidades aprendidas durante as várias fases da vida. A aprendizagem está diretamente relacionada com o desenvolvimento cognitivo. Criar uma afetividade com o aluno se torna cada vez mais uma via de transição, por onde passa o conhecimento. Piaget (1896-1980) reconheceu que a afetividade é o agente motivador da atividade cognitiva. Para ele, a afetividade e a razão constituem termos complementares: "É o interesse e, assim, a afetividade que fazem com que uma criança decida seriar objetos e quais objetos seriar" (PIAGET, 1967, apud LA TAILLE, 1992, p. 10). Este tema, acompanha o ser humano desde seu nascimento, se tornando fundamental em todo processo cognitivo e mecânico que se é submetido até a idade adulta, refletindo de forma significativa, na aprendizagem e no desenvolver musical.

Desde os primeiros dias do desenvolvimento da criança, suas atividades adquirem um significado próprio num sistema de comportamento social e, sendo dirigidas a objetivos definidos, são refratadas através do prisma do ambiente da criança. O caminho do objeto até a criança e desta até o objeto passa através de outra pessoa. Essa estrutura humana complexa é o produto de um processo de desenvolvimento profundamente enraizado nas ligações entre história individual e história social (VYGOTSKY, 1984. p 33).

$\mathrm{Na}$ concepção Vygotskyana, a interação social é de fundamental importância para o desenvolvimento do indivíduo enquanto ser social. Por meio dela, as atividades psicológicas tipicamente humanas se formam possibilitando ao indivíduo que transforme a si mesmo bem como o ambiente em que está inserido para atender às suas necessidades. $\mathrm{O}$ mesmo ocorre no processo ensino aprendizagem, no qual professor e aluno trocam experiências, e mediante esta interação são capazes de intervir um no comportamento do outro, visto que estão inseridos em um mesmo contexto social, histórico e cultural. 


\section{A prática pedagógica no Ensino da Música}

A pesquisa se desenvolveu em uma escola que atende a comunidade Quilombola nas imediações de Belo Jardim, a qual possui apenas três ambientes e atende a uma turma multisseriada composta por alunos de $1^{\circ}, 2^{\circ}, 3^{\circ}, 4^{\circ}$ e $5^{\circ}$ anos do ensino fundamental. Ao iniciar o estágio na Escola Quilombola, procuramos recuperar alguns conhecimentos construídos em um projeto de extensão, vivenciados por dois anos na sua comunidade. O projeto de extensão em Música intitulado "Batuque na cozinha, sinhá não qué: traçados de negritude e musicalidade no Agreste Pernambucano, que possibilitou o resgate da história musical dessa comunidade, serviu de base para nossa pesquisa-ação no que se refere à compreensão da musicalidade e tradições da escola e do entorno.

Desde os primeiros dias do desenvolvimento da criança, suas atividades adquirem um significado próprio num sistema de comportamento social e, sendo dirigidas a objetivos definidos, são refratadas através do prisma do ambiente da criança. O caminho do objeto até a criança e desta até o objeto passa através de outra pessoa. Essa estrutura humana complexa é o produto de um processo de desenvolvimento profundamente enraizado nas ligações entre história individual e história social (VYGOTSKY, 1984. p 33).

Quando iniciamos nosso projeto, Levávamos músicas e atividades relacionadas para que eles entendessem tanto na pate mais teórica como na parte prática. Além destas atividades, sempre mostrávamos algum instrumento a eles como forma também de estreitar nosso relacionamento e para que eles também soubessem um pouco como era nosso dia a dia enquanto músicos. Usando metodologias como a observação participante e as entrevistas não estruturadas, podemos então conhecer mais sobre os alunos e sobre suas famílias, fazendo com que tivéssemos mas oportunidades de trabalhar a musicalidade deles pois, suas famílias sempre participavam das mesmas e sempre os levavam independente de ser em horário de aula ou não 


\title{
Analisando a Aprendizagem e Desenvolvimento a partir da experiência de estágio
}

\begin{abstract}
A inserção da música na escola promove diversos acontecimentos que transcendem o ensinar e até mesmo o próprio aprender, na escola do Barro Branco tudo ficou mais visível por conta da grande interação que a escola possui com a comunidade, é um ciclo que só aumenta a cada dia, a escola tem muito respeito pela comunidade e a comunidade pela escola. Quando começamos nossa intervenção, a comunidade já passava por um processo de autorreconhecimento no que diz respeito a tradição de folguedo( músicas tradicionais da comunidade), por conta do projeto de extensão, já se havia conseguido fazer com que os mais antigos começassem a passar para os mais novos conhecimentos repassados para eles por seus antepassados (o que não vinha acontecendo causando a aculturação na comunidade).
\end{abstract}

\begin{abstract}
“[...] as distinções étnicas não dependem de uma ausência de interação social e aceitação, mas são, muito ao contrário, frequentemente as próprias fundações sobre as quais são levantados os sistemas sociais englobantes. A interação em um sistema social como este não leva a seu desaparecimento por mudança e aculturação; as diferenças culturais podem permanecer apesar do contato interétnico e da interdependência dos grupos.” (BARTH, IN: POUTIGNAT, 1998: 188)
\end{abstract}

A partir então de nossa inserção com o estágio, tanto as crianças como também os adultos puderam ligar os fatos com mais facilidade, pois, o que lhes foi mostrado de um modo mais superficial pelo projeto de extensão agora é aprofundado pelo estágio. Durante todo esse tempo de observação e regência fomos testemunhas de várias transformações que ocorreram na escola por conta da educação musical, antes mesmo do início da pesquisa os pais já nos relatavam da curiosidade das crianças por suas músicas tradicionais, após o estudo da música, os alunos não só se concentravam mais como também, interagiam mais, não só na disciplina artes/música, mas em um contexto geral, o rendimento escolar e também a forma de comportamento tanto na escola como fora dela aumentaram significavelmente 


\section{Conclusões}

A comunidade Quilombola do Barro Branco é só um dentre tantos e tantos exemplos de comunidades que tiveram suas realidades diárias transformadas a partir da educação musical, do fazer musical, do se reconhecer musicalmente, fazendo com que estas localidades desenvolvessem um olhar diferente principalmente no que diz respeito as suas perspectivas quanto ao futuro. Quando se começa a aprender música de alguma forma, seja cantando, tocando algum instrumento ou até mesmo estudando sobre o assunto, descobre se que esta transcende o tocar, o fazer musical, o dançar, o curtir, o divertir, descobre que sentimentos como o afeto, o respeito, a dedicação, a educação, estão diretamente ligadas neste desenvolvimento. Sendo este movimento a mola propulsora do ensino em nossas escolas, por onde passam tantos e tantos sonhos, fazendo com que a maioria destes se tornem realidade e para que um dia possamos ter a escola que sonhamos.

\section{Referências}

PIAGET, J. Le Jugement Moral chez L'enfant. 7.ed. Paris: PUF, 1992

PIAGET, J. O nascimento do raciocínio na criança. 5a. Ed. São Paulo: El Ateneo, 1993.

POUTIGNAT, Philippe; STREIFF-FENART, Jocelyne. Teorias da Etnicidade. São Paulo: Fundação Editora da UNESP, 1998.

VYGOTSKY, L.S. A Formação Social da Mente. São Paulo: Martins Fontes, 1984 